\title{
The Evolutionary Concept of the Morphology of Endosperm
}

\author{
By Ramesh Kumar SRIVASTAVA*
}

Received November 10,1952.

\section{Introduction}

The variance in the chromosomal composition of the endosperm of angiosperms has resulted in an increasing number of speculations regarding its morphology. The replacement of the archegonial apparatus by the embryo sac, with which the endosperm is associated, has further complicated the problem of assigning to the endosperm a definite position in the present categories of structures based on chromosome number, viz. gametophyte and sporophyte. In view of the present trends in genetical and embryological research, the need for elucidating the morphological nature of the endosperm appears genuine.

This paper aims at a critical review of the older theories of endosperm morphology and evolves, on the basis of recent researches, a plausible hypothesis which explains the basic nature of various developmental abnormalities in the endosperm of angiosperms.

\section{Theories of Endosperm Morphology}

As early as 1858, Hofmeister stated that the endosperm was a gametophytic tissue, and that its growth was postponed till the pollen tube entered the embryo sac. Since this opinion was held previous to the discovery of "syngamy" and "double fertilization", it has only historical interest.

In 1884, Strasburger discovered syngamy and in 1887, Le Monnier suggested that the fusion of the polar nuclei is equivalent to the act of fertilization. According to this view, therefore, the endosperm is a tissue of sporophytic nature and is actually another embryo modified for the nutrition of the first. Later investigation, however, revealed that the fusion of polar nuclei is not comparable to the act of fertilization, nor does the so-called second embryo always contain a diploid number of chromosomes.

Nawaschin announced the discovery of "double fertilization" in 1898 and regarded "triple fusion" as equivalent to normal fertilization, so that the endosperm was adjudged to be homologous to the normal embryo. Basing her conclusions on this view, Miss Sargant (1900) explained the absence of a struggle for existence between the two embryos as due to the participation of a vegetative nucleus from the

\footnotetext{
* Department of Botany, University of Allahabad, U.P., India.
} 
chalazal quartet in the formation of the second embryo. She homologised the micropylar polar nucleus to the egg and stated that the second embryo was "maimed" since its origin because the chalazal polar nucleus upset the chromosomal balance. Thus the endosperm was believed to be a degenerating sporophyte.

Sargant's views were based on the assumption that the involvement of the chalazal polar nucleus brings about a degeneration of the resultant formless tissue. It has, however, been recorded that the endosperm with its abnormal chromosomal constitution exhibits more vigorous growth than the embryo itself. Further, cases have been recorded where the endosperm is not a product of "triple fusion", as in Oenothera suaveolens (Hoeppener and Renner, 1929), Balanophora (Kuwada, 1928; Zweifel, 1939: Fagerlind, 1945) and Butomopsis (Johri, 1936). In these cases only the micropylar polar nucleus is fertilized and a normal endosperm (diploid) is produced. If Sargant's theory were correct, this diploid "embryo" should exert for its survival, a fact absent from developmental studies. Thus Sargant's views on endosperm morphology have only a very limited application.

Strasburger in 1900, interpreted "triple fusion" as a growth stimulus. He considered the endosperm to be a "belated gametophyte" which was initiated only after fertilization of the egg was ensured. He explained this postponement in the development of the gametophyte as an expedient adopted to prevent the waste of material accompanying every unfertilized ovule. "Triple fusion" acted as a sitmulus which prompted the growth of the gametophyte after fertilization had taken place.

The origin of "triple fusion" as a growth stimulus has received confirmation at the hands of recent workers. Battaglia (1951) has concluded, from a study of apomictic species of angiosperms, that "the union of secondary nucleus and male nucleus serves primarily as a mitotic stimulus". It is, however, certain that the fusion of the male nucleus is not an "absolute" sine qua non for endosperm formation but a stimulus is, nevertheless, necessary. This is clearly demonstrated by the studies on Taraxacum (Fagerlind, 1947 ; Battaglia, 1948), Chondrilla (Bergman, 1944 ; Battaglia, 1949), Erigeron (Bergman, 1944; Fagerlind, 1947a ; Battaglia 1950), Hieracium (Rosenberg, 1930), Elatostema (Fagerlind, 1944) and other parthenogenetic species. Thus, Strasburger's views on the universal function of "triple fusion" are not very correct.

Strasburger's idea that the endosperm is a belated gametophytic tissue must also be abandoned in view of the existence of an increasing number of embryo sacs where the characteristic haploid nature of the endosperm is lacking.

Thomas, quoted by Sargant (1900), was of opinion that the second male nucleus probably imparts to the resultant tissue a chromosomal status which better suits the needs of the embryo arising from a similar stock. In 1910, Nemec suggested that "triple fusion" serves a dual role in endosperm formation; first, of initiating its development and second, of creating for the embryo a "physiologically compatible" tissue. 
Brink and Cooper $(1940,47)$, explaining the nature of the endosperm, pointed out that "double fertilization" "emerges as a mechanism which enhances aggressiveness of the endosperm through the physiological advantages of a hybrid condition. It may also be thought of as a compensatory device tending to offset the disadvantage in reproduction associated with the extreme reduction of the female gametophyte in angiosperms." On examination, the views of Thomas, Nemec, and Brink \& Cooper would appear to be based on the assumption that a male nucleus invariably participates in endosperm formation. But this is not a universal phenonenon. Secondly, reports of a normal endosperm in parthenogenetic plants repudiate the suggestion of "aggressiveness of the endosperm through the physiological advantages of a hybrid condition." Again, the views of Thomas and Nemec stress the physiological suitability of the "hybrid" endosperm for the growing embryo. The chromosomal constitution of the angiospermous endosperm has, however, been so variable that such a statement needs no further arguments for refutation.

Battaglia (1951) questioned the propriety of the term "double fertilization" and stated that "the significance of the normal union (of polar nuclei) with a male nucleus is evidently that it furnishes stimulation to overcome a phase of mitotic inertia."

The views of Brink and Cooper, and Battaglia do not throw any light on the morphological nature of the endosperm.

\section{Phylogenetic History of the Endosperm}

With the background of such conflicting opinions, an exclusive and systematic study of the origin and nature of the endosperm of spermatophyta merits attention.

In a large majority of, gymnosperms, the endosperm is, in effect, only the vegetative portion of the female gametophyte which is wholly formed before fertilization. In addition to this tissue, in exceptional cases, there is produced a small amount of nutritive tissue, by the fusion of a male nucleus and the ventral canal nucleus. Such cases have been recorded in Thuja (Land, 1902), Abies balsamea (Hutchinson, 1915), Pseudotsuga taxifolia (Allen, 1943) and Ephedra (Herzfeld, 1922; Khan, 1940; Mulay, 1941). As a result of this fusion in the archegonium, a small amount of vegetative tissue is produced which is used up by the embryo during growth.

In Gnetum and Welwitschia (Pearson, 1929), in which the female gametophyte is either free nucleate or composed of multinucleate compartments at the time of fertilization, the nuclei in the multinucleate chalazal compartments fuse and form uninucleate cells. These undergo cell division to produce the final endosperm.

Before fertilization, in angiosperms, there is present in the central part of the embryo sac, a secondary nucleus (product of the fusion of two polar nuclei) or a "proendospermatic cell" (containing two distinct polar nuclei). In the chalazal part 
of the embryo sac, there is present a variable number (usually three) of uninucleate compartments, the antipodals. In some cases they have been found to be binucleate as the superior antipodal in Rudbeckia purpurea (Battaglia, 1946), Rudbeckia bicolor (Maheshwari and Srinivasan, 1944), Artemisia (Diettert, 1938) and Grindelia squarrosa (Howe, 1926). In Artemisia and Phyllis (Fagerlind, 1936), there is a very variable number of nuclei in antipodal cells and the antipodals of Caltha palustris (Grafi, 1941) exhibit a varying degree of polyloidy. In certain Gentianaceae and Gramineae the number of antipodals is variable, while in Sasa paniculata (Yamaura, 1933), a member of the Bambusae as many as 300 antipodals are present. Battaglia (1910) has reported mitotic activity in the antipodals of Ligularia Kaempferi before fertilization. This phenomenon of "polyantipody" is regarded as a representative of prefertilization endosperm in angiosperms.

Simultaneous with the union of the egg and one male nucleus is the fusion of the second male nucleus and the secondary uncleus. This fusion product gives rise to a mass of free nuclear or cellular tissue which is consumed by the growing embryo. The endosperm initial sometimes divides and produces a normal endosperm without fusing with a male nucleus (vide supra).

Thus the endosperm is spermatophyta is of two distinct categories, pre-fertilization and post-fertilization. The phylogeny of the Spermatophyta endosperm can be summarised thus:

\begin{tabular}{|c|c|c|c|}
\hline Group & Section & $\begin{array}{c}\text { Primary } \\
\text { Endosperm }\end{array}$ & $\begin{array}{l}\text { Secondary } \\
\text { Endosperm }\end{array}$ \\
\hline Gymnosperms & general & $\begin{array}{c}\text { Female gametophyte } \\
\text { (Haploid) }\end{array}$ & $x$ \\
\hline "I & $\begin{array}{l}\text { Thuja, Abies Pseudo- } \\
\text { tsuga and Ephedra }\end{array}$ & " & $\begin{array}{l}\text { Tissue formed by the } \\
\text { fertilization of the } \\
\text { ventral canal nucleus } \\
\text { (Diploid) }\end{array}$ \\
\hline " & $\underset{\text { tschia }}{\text { Gnetum and Welwi- }}$ & $\begin{array}{l}\text { Free nucleate or multi- } \\
\text { nucleate-cells of female } \\
\text { gametophyte (Haploid. } \\
\text { polyploid) }\end{array}$ & $\begin{array}{l}\text { Tissue formed by the } \\
\text { division of uninucleate } \\
\text { cells (Polyploid) }\end{array}$ \\
\hline Angiosperms & $\begin{array}{l}\text { Gentianaceae, Gramineae } \\
\text { and Caltha palustris etc. }\end{array}$ & $\begin{array}{l}\text { Tissue formed by poly- } \\
\text { antipody (Haploid to } \\
\text { polyploid) }\end{array}$ & $\begin{array}{l}\text { Tissue formed by the } \\
\text { division of the endo- } \\
\text { sperms initial (Diploid } \\
\text { to polyploid) }\end{array}$ \\
\hline$" \prime$ & general & 一 & " \\
\hline
\end{tabular}

In such a review of the phylogeny of the endosperm, another feature can be easily observed. This concerns the mounting importance of the process of "stimulation".

In gymnosperms, the gametophyte which functions as the embryonic nutriment develops to its full stature without any stimulus. In Thuja, Abies Pseudotsuga and 
Ephedra where the ventral canal nucleus is not ephemeral, stimulation is received from the fusion of the male nucleus with the ventral canal nucleus and the few mitotic divisions from the post-fertilization endosperm. In Gnetum and Welwitschia, the post-fertilization endosperm is almost exclusively developed through the agency of the stimulus provided by the fusion of the nuclei in multinucleate compartments. Polyantipody of certain angiosperms is again an instance of stimulation by the fusion of nuclei in polynucleate antipodals. Finally the secondary endosperm of most angiosperms develops only after the stimulation provided by fusion of polar nuclei is supplemented by the fusion of the male nucleus.

\section{Evolutionary Concept of Endosperm Morphology}

A critical examination of these facts of endosperm phylogeny elucidate the presence of three principal tendencies which gradually assume increasing significance in the developmental processes of the endosperm. These are:

(1) An increase in number of its chromosomes; (2) a shift in its position in relation to fertilization; and (3) an enhancing demand for stimulation in its initiation. These tendencies are perfectly harmonious with the idea of evolution in the endosperm and its necessary genetical advancement.

Thus, from the simple haploid endosperm of most gymnosperms, a progressive series can be traced upwards to Ephedra where there is a beginning of the formation of a post-fertilization tissue. However, concurrent with the advance of the Sporophyte, there is an increasing necessity of stimulation. This coupled with the shift in the position of the endosperm, necessitates the provision of nuclear fusions. In the initial stages of this process, the nuclear fusions are restricted to the female parent alone, as in Gnetum and Welwitschia. But a step further in the progress finds fusion of maternal nuclei an insufficient provocation for the development of the endosperm. This can be attributed to the longer period for which the polar nuclei of the angiosperms lapse into a mitotic inertia. This longer phase is overcome by participation of the sec $\oplus$ nd male nucleus. Nevertheless, in a few primitive cases, the phenomenon of maternal nuclear fusions is retained for the pre-fertilization endosperm (polyantipody).

The course of evolution can now be traced separately in primary as well as secondary endosperm.

\begin{tabular}{|c|c|c|c|}
\hline Primary: & $\begin{array}{r}\text { Haploid ..... } \\
\text { (Gymnosperms } \\
\text { up to Ephedra) }\end{array}$ & $\begin{array}{l}\text { multinucleate compartment } \\
\text { (Gxetum and Welwitschia) }\end{array}$ & $\begin{array}{l}\text {... Haploid to Polyploid } \\
\text { (Gentianaceae, Gramineae } \\
\text { Caltha, Ligularia } \text { etc.) }\end{array}$ \\
\hline Secondary: & $\begin{array}{c}\text { Diploid ...... } \\
\text { (Ephedra etc.) }\end{array}$ & $\begin{array}{c}\text {.......... Polyploid .............. } \\
\text { (Gnetum and Welwitschia) }\end{array}$ & $\begin{array}{l}\text {.. Diploid to Polyploid } \\
\text { (Angiosperms) }\end{array}$ \\
\hline
\end{tabular}

In the light of these lines of progress, the parthenogenetic cases in Taraxacum, Erigeron, Antennaria and Hieracium etc. provide an interesting clue to the nature 
of the endosperm. It is apparent that these cases represent a regressive series which displays a primitively constituted endosperm. But the advanced condition of their embryo sacs does not warrant such a primitivity. These can, therefore, be interpreted as the advanced cases which display probably atavistic features of endosperm development. However, the very existence of cases where the "proendospermatic cell" is capable of autonomous division to produce normal endosperm proves that the essential nature of the secondary nucleus is of fundamental importance in guiding the destiny of the future endosperm. This nucleus forms the true endosperm initial and requires no aid in its future activity. In other cases, stimulus is required but the "original function" is not changed to the slightest extent. Thus the participation of the second male nucleus is a purely adaptive phenomenon which occurs in the course of evolution.

Out of these evolutionary sequences in endosperm development, three facts emerge: (1) that the endosperm is formed invariably in all cases; (2) that it invariably serves as the nutrient tissue for the embryo; and (3) that its composition is variable in accordance with a set pattern.

The formulation of an evolutionary concept of endosperm morphology is the consequence of such an analysis.

Prima facie evidence establishes that the endosperm of angiosperm is a "predestined tissue" designed from the first to serve as the nutriment of the developing embryo, in spite of a variability in its chromosomal make-up. The raison d'etre of of the endosperm being solely the nourishment of the embryo, adaptibe modifications of a physiologico-evolutionary type must be given preponderance in considerations of morphology.

The basic material of the endosperm was a haploid tissue of gametophytic nature. This was gradually converted to diploid, triploid and polyploid state as the evolutionally series progressed. Even in the angiosperms, the composition of the endosperm varies. In primitive Oenothera it is diploid, in Polygonum, Adoxa and Drusa triploid, and in Ditepalanthus tetraploid. Pentaploid endosperm is present in Fritillaria, Plumbagella, Penaea and Plumbago, while a nonaploid condition is seen in Acalypha indica and species of Peperomia. In Peperomia hispidula the endosperm nucleus is the fusion product of fourteen polar nuclei and a male nucleus, while in species of Pandanus even cells of the nucellus enter into the composition of the endosperm.

This absence of a constancy in chromosomal constitution forms the basis of the hypothesis that the endosperm of angiosperms is a tissus sui generis which cannot be classified in the rigorous chromosomal categories, viz., gametophyte and sporophyte, and though haploid at origin, the final product at the end of the evolutionary sequence can no more be designated as either haploid or diploid. 


\section{Phylogenetic Considerations of the Fate of Male Nuclei}

In explaination of the behaviour of the second male nucleus, it has been stated: (1) The utilization of both sperms may be considered to be the result of the presence, in the theoretical preangiosperms, of two equipotential male nuclei and (2) It seems probable that the interaction of forces, almost certainly physiological...... permits the union of male nuclei with both egg and secondary nuclei. (Battaglia 1951)

The gymnosperms being anemophilous, a large number of microspores are wasted. Of the many germinating microspores on the nucellus, a few send their pollen tubes to the archegonia. Usually, if the two male nuclei from one pollen tube enter one archegonium, only one male nucleus fuses with the egg and the other degenerates. Thus, in spite of a number of archegonia, male nuclei are wasted in most gymnosperms. Again, of the many embryos thus formed, eventually only one survives. Thus there is a three-fold waste of energy: (1) In the degeneration of one male nucleus per microspore, (2) In the formation of many archegonia in one ovule, and (3) In the formation and subsequent degeneration of all embryos except one. In cases where the second male nucleus fuses with the ventral canal nucleus, there may be distinguished a conservation of energy by avoidance of the first condition. In Gnetum, the archegonia disappear and every one of the free nuclei of the female gametophyte acts as a potential egg. There is thus an attempt to secure the services of the extra male gametes. In angiosperms, with a tendency towards conservation of microspores by entomophily, there exists an extreme reduction of the female gametophyte, so that only one functional egg is present. Thus, the second condition is sucessfully counteracted. Now, in order to prevent the waste due to (1) and (3), the second male nucleus should neither degenerate nor give rise to a second embryo.

At this stage of evolution, the fusion of the polar nuclei fails to arouse the proendosperrmatic cell from mitotic inertia.

The concurrence of these two conditions results in a physiological adaptation by which the second male nucleus fuses with the proendospermatic cell. This fusion prevents the waste of energy of all three types and furthers the growth of the endosperm.

Thus, while the transposition of the endosperm from pre-fertilization to postfertilization status may be reckoned to be a physiologico-evolutionary modification, the fusion of the second male nucleus with the endosperm nucleus may be regarded as purely physiological and a more or less coincident process, which has come to be stabilized in the angiospermous series. 


\section{Summary}

A critical review of the existing theories of endosperm morphology has been attempted.

In accordance with a reconsideration of endosperm phylogeny, an evolutionary concept has been suggested to explain the various aspects of the development of endosperm. Evolutionary trends have been discussed on three main lines:

1. Increasing complexity in chromosomal constitution;

2. Gradual transposition in relation to fertilization; and

3. Dominance of mitotic inertia and demand for stimulation.

Consideration of these guiding tendencies coupled with the existence in apomictic plants of an autonomous endosperm, has resulted in the formulation of the theory of the "pre-destined" nature of the endosperm.

It is shown that the endosperm in angiosperms is a tissue sui generis which should not be classified in rigorous chromosomal categories.

The role of physiologico-evolutionary modifications is shown to be reinforced by a purely physiological coincidence, the fusion of the second male nucleus with the proendospermatic cell.

\section{Literature Cited}

Allen, G. S., 1943: The Embryogeny of Pseudotsuga taxifolia (Lamb.).-Britt. Amer. J. Bot. 30 : 655-661.

Battaglia, E., 1940: Embryologia di Ligularia Kaempferi Sieb. et. Zucc.-Nuovo Gior. Bot. Ital. $47: 271-286$.

., 1946: Ricerche cariologiche ed embriologiche Sul genere Rudbeckia (Asteraceae). I-V, Il gametofits femminile e maschile di $R$. bicolor Nutt, $R$. hirta L., $R$. hirta L. var. Meine freude Hort, R. amplexicaulis Vahl. e R. purpurea L. (Echinacea purpurea Moench).-Nuove Gior. Bot. Ital. $53: 1-26$.

1948: Ricerche sulla parameiosi restituzionale nel genere Taraxacum.-Caryologia. 1: 1-47. 1949: L'alterazione della meiosi nella riproduzione apomittica di Chondrilla juncea L.Caryologia. $2: 23-30$.

, 1950 : L'alterazione della meiosi nella riproduzione apomittica di Erigeron Karwinskianus DC. var. mucronatus DC. (Asteraceae).-Caryologia. 2 : 165-204.

., 1951: The male and female gametophytes of angiosperms-an interpretation.-Phytomorphology (India). 1: 87-116.

Bergman, B., 1944: A contribution to the knowledge of the embryo sac mother cell and its develop. ment in two apomicts.-Svensk bot. Tidskr. 38: 249-259.

Brink, R. A. and Cooper, D. C., 1940: Double fertilization and development of the seed in angiosperms.-Bot. Gaz. $102:$ 1-25.

, 1947: Endosperm in seed development.-Bot. Rev. 13: 423-541.

Chamberlain. C. J., 1943: “Gymnosperms" University of Chicago Press.

Diettert, R. A., 1938: The morphology of Artemisia tridentata Nutt.-Lloydia. $1: 3-74$. 
Fagerlind, F., 1936: Embryologische Beobachtungen uber die Gattung Phyllis.-Bot. Notiser 1936, pp. 577-584.

. 1945: Bildung und Enturicklung des Embryosacks bei Sexuellen und agamospermischen Balanophora Arten.-Suenok bot. Tidskr. 39:65-82.

., 1944: Die Samenbildung und die Zytologie bei agamoppermischen und sexuellen Arten von Elatostema und einigen nahestehenden Gattungen nebst Beleuchtung einiger damit Zusammen hangender Probleme.-K. Svenska Venterisk. Akad. Handl. 21 : 1-130.

., 1917a : Die Restitutions-und Kontraktionskerne der Hieracium-Mikrosporogenese.-Svensk bot. Tibskr. $41: 247-263$.

, 1947b: Makrosperogenese und Embryosackbildung bei agamospermischen TaraxacumBiotypen.-Svensk bot. Tidskr. $41: 365-390$.

Grafi, I., 1941: Über das Wachstum der Antipodenkerne von Caltha palustris.-Chromosoma. 2: 1-11.

Herzfeld, S., 1922 : Ephedra campylopoda Mey. (cit. by Chamberlain, 1935).

Hoeppener, E. and Renner, O., 1929: Genetische und zytologische Oenotheren-studien, II.-Bot. Abb. Goebel. 15: 1-86.

Hofmeister, W., 1858: Neure Beobachtungen über Embryobildung der Phanerogamen.-Jahbr. f. Wiss. Bot. 1: 82-186.

Howe, T. D., 1926: Development of embryo sac in Grindelia squarrosa.--Bot. Gaz. 81 : 280-296.

Hutchinson, A. H., 1915: Fertilization in Abies balsemea.-Bot. Gaz. 60: 457-572.

Johri, B. M., 1936: The life history of Butomopsis lanceolata Kunth.-Proc. Ind. Acad. Sci. B. 4: 139-162.

Khan, R., 1940: A note on "double fertilization" in Ephedra foliata-Curr. Sci. (Bangalore). 9 : 323325 .

Kuwada, Y., 1928: An occuarence of restitution nuclei in the formation of the embryo sace in Belanophora japonica, Mak.-Bot. Mag. (Tokyo) 42: 117-129.

Land, W. J.G., 1902: A morphological study of Thuja.-Bot. Gaz. 34: 243-259.

., 1904: Spermatogenesis and oogenesis in Ephedra trifurca.-Bot. Gaz. 38: 1-18.

Le Monnier, G., 1887: Sur la valeur morphologique de l'albumen chez les angiospermes.-Jour. de Bot. (Paris) $1: 140-142$.

Maheshwari, P., 1948: The angiosperms embryo sac.-Bot. Rev. 14: 1-56.

., 1950: "An Introduction to the Embryology of Angiosperms."-Mc. Graw Hill Book Co., New York.

., and Srinivasan, A.R., 1944: A contribution to the embryology of Rudbeckia bicolor Nutt.-New Phytol. $43:$ 135-142.

Mulay, B. N., 1941: A study of the pistillate plants Ephedra foliata Boiss., found at Drigh Road near Karachi in Sind.-Proc. Indian Sci. Congr. 28.

Nawaschin, S. G., 1898: Resultate einer Revision der Befruchtungsvorgange bei Lilium martagon Fritillaria tenella.-Bul. Acad. Imp. des. sci. st. Petersburg. $9:$ 377-382.

Nemec, B., 1910: "Das Problem der Befruchtungsvorgange und andere zytologische Fragen."Berlin.

Pearson, H. H. W., 1929: “Gnetales”. Cambridge University Press.

Rosenberg, O., 1930: Apogamie und Parthenogenesis bei Pflanzen.-Handb. Vererb. Wiss. 12:1-66.

Sargant, E., 1900: Recent work on the results of fertilization in angiosperms.-Ann. Bot. 14: 
689-712.

Srivastava, R. K., 1951: A note on the evolution and morphology of the endosperm. (unpublished). ., 1952: The Evolutionary Concept of tne Morphology of the Endosperm-An Abstract.-Proc. Nat. Acad. Sci. (India). (In Press)

Stebbins, G. L., 1932a: Cytology of Antennaria I. Normal species.-Bot. Gaz. 94: 134-151. , 1932b: Cytology of Antennaria II. Parthenogenetic species.-Bot. Gaz. 94: 322-344.

Stork, H.E., 1920: Studies in the genus Taraxacum.-Bull. Torrey Bot. Club 47: 199-210.

Strasburger, E., 1884: “Neue Untersuchungen über den Bfruchtungsvorgang bei den Phanerogamen als Grundlage fur eine Theorie der Zeugung."-Jena.

., 1900: Einige Bemerkungen Zur Frage nach der doppelten Befruchtung bei Angiospermen.-Bot. Ztg. II, $58:$ 233-316.

Tinney, F. W., 1940: Cytology of Parthenogenesis in Poa pratensis.-J. Agric. Res. 60 : 351-360.

Yamaura, A., 1933: Karyologische und embryologische Studien über einige Bambusa-Arten. (Vorlaufige Mitteilung).-Bot. Mag. (Tokyo) 47: 551-555.

Zweifel, R., 1939: "Cytologisch-embryologische Untersuchungen an Balanophora ebbreviata Blume und B. indica."-Diss., Zurich. 